$\pm N / N$

Global Journals Inc.

की

\title{
Thinking Forgetting Through: Maurice Blanchot, for Example
}

By David Appelbaum

SUNY New Paltz

Abstract- Much of Blanchot's thought seeks to undo the safe, secure interiority of early Heidegger. It takes the form of a radical nihilism open to the outside, where a swatch of irredeemable negativity exposes language and being to a corrosive contaminant while effacing all transcendental signifieds. The result is the impenitent-the forgetting that antedates all memory. Yet the trace of the immemorial persists and persistently indicates the beyond being, which is the sacred. A light-hearted unconcern-a kind of reduction of ontic appropriativity-then constitutes a way to (of) the outside, a non-place absolutely lacking in an inside. Metaphorically, the insouciance of casual reading (rather than one that digs for the profundity) offers access to an inaccessible text, a text made inaccessible by the reach for meaning. The sacrifice Blanchot has in mind, in going beyond that of the object of thought, requires a total rehabilitation of thinking. Thought as forgetting becomes the dissembled auto-affection of the outside. Such thinking bears the mark of a primordial affirmation, the sacral Yes.

GJHSS-A Classification: FOR Code: 190499

Strictly as per the compliance and regulations of:

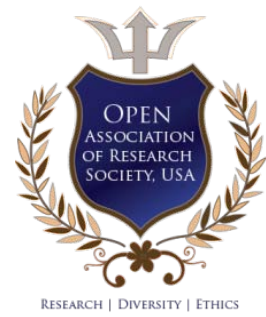

(C) 2020. David Appelbaum. This is a research/review paper, distributed under the terms of the Creative Commons AttributionNoncommercial 3.0 Unported License http://creativecommons.org/licenses/by-nc/3.0/), permitting all non-commercial use, distribution, and reproduction in any medium, provided the original work is properly cited. 


\title{
Thinking Forgetting Through: Maurice Blanchot, for Example
}

\author{
David Appelbaum
}

\begin{abstract}
Much of Blanchot's thought seeks to undo the safe, secure interiority of early Heidegger. It takes the form of a radical nihilism open to the outside, where a swatch of irredeemable negativity exposes language and being to a corrosive contaminant while effacing all transcendental signifieds. The result is the impenitent-the forgetting that antedates all memory. Yet the trace of the immemorial persists and persistently indicates the beyond being, which is the sacred. A light-hearted unconcern-a kind of reduction of ontic appropriativity-then constitutes a way to (of) the outside, a non-place absolutely lacking in an inside. Metaphorically, the insouciance of casual reading (rather than one that digs for the profundity) offers access to an inaccessible text, a text made inaccessible by the reach for meaning. The sacrifice Blanchot has in mind, in going beyond that of the object of thought, requires a total rehabilitation of thinking. Thought as forgetting becomes the dissembled auto-affection of the outside. Such thinking bears the mark of a primordial affirmation, the sacral Yes.
\end{abstract}

\section{INTRODUCTION}

4 he disaster is related to forgetfulness-forgetfulness without memory, the motionless retreat of what has not been treated-the immemorial, perhaps. To remember forgetfully: again, the outside.' [WD 3]

'The time of affliction: a forgetting without forgetting, without the possibility of forgetting.' [IC 195]

Blanchot's habit is of re-appropriating words, assigning different significations to concepts already amply imbued with meaning, eviscerating their vitality, turning them inside out. The operative is the term 'without.' Imagine Blanchot's thought without 'without.' Derrida catalogs the list on which Blanchot practices the procedure. ${ }^{1}$ One could say that the without is an indicator of dissimulation. Most famously, 'relation without relation' tries to alert us that what appears as relation is 'in reality' dissimulating something other than relation (which, in an 'advanced' age of simulation would be another simulacrum.) A relation without relation between one and the other signifies the 'inaccessibility' of relating, and 'that this inaccessible relation sets up... the inaccessible presence of the other-man without horizon-who becomes relation and

Author: Department of Philosophy, SUNY, New Paltz. e-mail:appelbad@newpaltz.edu

\footnotetext{
1 'Sans [without, -less] plays like a strange spring, neither a force [energie] nor a function [fonctionnement].' 'Pace Not(s)', in Parages, ed. John P. Leavey, tr. Tom Conley, James Hulbert, John P. Leavey, and Avital Ronell. Stanford: Stanford University Press, 2011, p. 77.
}

access in the very inaccessibility of his approach.'2 Doing without, avowal of the lack, should not be taken as a dialectical negation-which can then be subsumed under a higher synthesis. It is rather Bataille's 'unemployable negation,' the negative beyond the yesno duality, which is to say, beyond the traditional diacritical matrix of meaning in which discourse conducts its business and harnesses its ends. Here, 'without' is an indicator (in Husserlian terms); it points to rather than expresses the outside-that which remains absolutely separate without being able to be separated. Blanchot feels such non-dialectical indication belongs to a neutral or neuter language.

What about forgetting without forgetting? As a term, it too would be employed to point to a dissimulation. It would not, however, involve dissimulations that could be realized, for example, in psychoanalysis, where repression dissimulates itself through displacement, condensation, and disguise. To acknowledge the movement there leads one to a depth in which successive syntheses expand the signification of the secret-the memory trace withheld by the person from herself. Analysis of dissimulation then informs the very subject under investigation, her drives, their exciting factors and valuations. By contract, 'without' [with-out] as an index involves a dissimulation so empty of meaning that it renders any possible meaning inoperative. 'Without' undoes depth, displays an empty secret, leaves repetition a numerical redundancy; while abandoning speaking nonetheless tells what always has been said already. In other words, Blanchot's operative weaponizes the preposition with the desoeuvrement [unworking or worklessness] of the outside. Nothing withstands its approach which, in the concomitant withdrawal, saps vitality from meaning like a parasite. [Indeed, Derrida's conception of parasitism is an evocation of the outside.] In forgetting without forgetting, forgetting becomes intransitive. No event, happening, or occurrence is the object of forgetting. Nothing is.

Forgetting in itself-as transitive-is subsequent to an event, memorable consciously or not. Ordinarily, one forgets a memory, for instance, my wife's birthday (which I know perfectly well but haplessly forgot.) One can also forget something that was never

\footnotetext{
2 Maurice Blanchot, The Infinite Conversation, tr. Susan Hanson.
} Minneapolis: University of Minnesota Press, 1993., p. 74. IC 
remembered, for instance, my birthday party at age 7 (because it was boring), because the trace was rendered unreadable. Forgetting is to remembering as inscribing is to erasing. This second kind of transitive forgetting sounds a lot like what Heidegger has in mind in the first Introduction to Being and Time. In the first sentence, he says, 'This question [of the meaning of being] has today been forgotten-although our time considers itself progressive in again affirming "metaphysics."'3 Here, to further determine what dissimulation is, Heidegger posits concealment [Verborgenheit] as the agency that shuts down truth as aletheia. Truth or self-being is repeated misremembered on the basis of a social persona, a construct made of what one thinks that others think of oneself. Such forgetting, however, is always already about being. It may lack a determinate object but has an enigmatic, indeterminate one [the ens transcendentia]. It takes a forceful reconsideration-the call of conscience-for memory to get back on track. To be able to remember that one exists (the regression of Cartesianism), to want to have a conscience, designates a forgetting that is potent enough to evoke its opposite. Dasein recoils from the threat of non-being and is remembered. The potentiation is related to that of death and its possibilizing of impossibility.

The forgetting Blanchot has in mind, forgetting outside itself (forgetting that lacks an ipse) is absolutely other. It is 'that which, in other words, cannot be forgotten because it has always already fallen outside memory.' ${ }^{4}$ It has 'fallen' even farther than the horizon of the subject, if we agree that experience always has the possibility of being recalled. It is beyond an event of 'subjectivity without the subject' since the limits and identity of any purported cache of experience to be so designated preclude immemorability. The fallen-ness [Verfallen] is of an order infinitely vaster than Heidegger's version of Verfangnis, the muting of the call of conscience, whereby Dasein lives in a perpetual confusion between the ontic and the ontological. The fall that Blanchot has in mind is more like that into Levinas' il y $a$-a non-region (non-lieu) of sheer being without presence, an excess absolutely lacking any order, lawless, anonymous, Plato's khora. The loss is so extreme that predication is inoperative. Nothing can be called anything since the means of one thing inhering in another have been annulled. The result is not silence but babble, murmuring, or as Levinas says about cognitive processes, the rumble of 'reservations of thought.'

\footnotetext{
${ }^{3}$ Martin Heidegger, Being and Time, tr. Joan Stambaugh. Albany: State University of New York Press, 1996, p. 1.

${ }^{4}$ Maurice Blanchot, The Writing of the Disaster, tr. Ann Smock. Lincoln: University of Nebraska Press, 1986, p.28. WD
}

Blanchot here also wants to go farther when he expresses 'forgetfulness as thought. ${ }^{5}$ Thought would become a dissimulation of absolute forgetting; it would lend the appearance of cognitive activity which would in fact be the illusory displacement of a nameless passive force that lacks all depth of signification. It is a step that changes the nature rather than the degree of thinking. It advocates abandon of an appearance/reality polarity. If forgetting as absolutely other is absolute disorder, thought no longer operates on the basis of truth, the disclosure of the real; shades on Heidegger on errancy. To be able to say whether a remembered event in fact happened or was imagined to happen is impossible. There is no transcendental signified, only the infinite play of signifiers, substituting one for another. The horde of polarities of 'metaphysics' go by the board: fact/fiction, presence/absence, real/fantasy. Moreover, the thoughtful play of forgetfulness does not restrict thinking to a forbidden or overlooked preserve but rather stigmatizes thought as the other, the other as thought. One could say, following Deleuze, that the fall renders thought as proximity, nearness, or closenessimmanence in short. It is a blank receptacle for becoming-creative, an experimental form to be seized by a passivity incapable of appropriation, a 'line of flight.' At the same time, however versatile thought remains, it cannot think being, i.e., forgetting 'forbids all presence of thought-all power to conduct thought as far as presence (as far as being).' 6

Forgetting, in this sense, ruins thought as a vehicle for good sense by stripping it of all teleology; 'thus would thought fall outside all teleology and perhaps outside its site. ${ }^{17} \quad$ To withhold arrival at the end (aim or cessation alike) is thought's responsibility. One could say that dying holds thought consciencebound for Blanchot in the way that death does being-inthe-world for Heidegger. Dying becomes the counterconcept to living, taking the place of death in Being and Time. But whereas death is empowered to give back life, to return thought (and Dasein) to being, dying has another assignment. It unworks life, renders thought inoperative and moves it, as Blanchot says, 'toward the precipice, the sheer fall, headlong.' ${ }^{8}$ Paradoxically one can ask, as the protagonist of Awaiting Oblivion does, 'Would forgetting be the only remembrance commensurate with death?' 9 Thus, the triad forgetting, thinking, dying appears as a post-lapsarian list of traits, human existence after the fall from the reality that metaphysics institutes-although 'after' does not designate any chronological order. The appearance too is dissimulation. The disaster, an occurrence that never

\footnotetext{
${ }^{5}$ idem

${ }^{6}$ The Writing of the Disaster, p. 33.

${ }^{7}$ Ibid., p. 39.

${ }^{8}$ Ibid., p. 40

9 Maurice Blanchot, Awaiting Oblivion, tr. John Gregg. Lincoln: University of Nebraska Press, 1997, p. 46. AO
} 
takes place because it always already has, implicates the other time, non-sequential, non-linear, nonsuccessive. Forgetting is 'earlier' than good sense (thought, memory) as it is then able to dissemble discursive thinking.

Forgetting thus becomes a counter- or codename for the outside, the non-place that escapes all naming. Does it bear a relation to discursive, dialectical forgetting, as in 'I forget my wife's birthday'? Perhaps only through another tag that Blanchot gives the outside, the immemorial. Because of the immemorial's shiftless vibrancy, to mark this or that is impossible. With nothing to stick onto, there is a repeated return to inscription in the face of the 'disastrous instability,' but without accomplishment. ${ }^{10}$ No object is able to presence because the very movement of presencing effaces itself as soon as it is initiated. The absent moment of presence signifies a past that must remain immemorial since the living present is necessary for what passes for experience and its trace. Empty of experience, however, does not mean empty of consciousness. The immemorial breeds consciousness as passivity ('more patient that passivity'), subjected to assault by the inconstant and repetitive streaming of images and linguistic fragments. Levinas' analysis of insomnia throws a spotlight on the peculiar vigilance that is unable to withdraw from awareness because it has become possessed and has surrendered its mastery over endings. It also suggests that Blanchot would embrace the outside as the il y a, Levinas' term for bare being, a transdescendence rather than transascendence of the ontic. Blanchot does say, in the mouth of one of his protagonists, 'Being is yet another word for forgetting. ${ }^{11}$

Absolute forgetting belongs to no one (has no genitive case) since contact effaces sovereignty, along with identity and difference. It is an amnesiac whose effects are more global than personal. [Blanchot: 'That forgetting speaks in advance in every word that speaks does not only signify that each word is destined to be forgotten, but also that forgetting finds its repose in speech and keeps speech in accord with that which is hidden. ${ }^{12}$ ] Its advent cannot be contained by subjectivity. Thus its powerlessness has the strange result of invading interpersonal space. Blanchot: 'The one who, forgetting, is effaced from us in this forgetting also effaces in us the personal ability to remember; then the impersonal remembrance is awakened, the personless remembrance that takes the place of forgetting for us.'13 'Impersonal remembrance' eradicates human history as well as all personal records of events. The remainder is empty to excess. The

\footnotetext{
${ }^{10}$ The Writing of the Disaster, p. 89.

${ }^{11}$ Awaiting Oblivion, p. 35.

12 Ibid., p. 46.

${ }^{13}$ Ibid., p. 38.
}

excessive emptiness, like a black hole, exerts a fascination that draws the attention to it; impotency as a weak force. The renewed encounter excites a countermemory of being threatened by nothingness. Whoever succumbs to fascination risks opening a horizonless space that cannot be confined to this or that person. Absolute forgetting contaminates absolutely, happily crossing boundaries of persons, like the air between us. It is safe to say that once let out of the bag (like Pandora's hope), remembrance of the outside is here to make repeated entries into everyday life.

The lack of memory-traces, the terrified welcome due the outside, the impersonal menace of remembering the immemorial: the definite descriptions make it seem that Blanchot speaks of a rare or abstruse phenomenon. This is not the case. The outside is actually familiar to all: it is found in the fact of obscurity. III-lit, partially blocked, at a bad angle, distraction, confusion: deficiencies that condition perception allow leakage of forgetting into the presentation of presence. They, moreover, are normal operating conditions. Blanchot frames his discussion of obscuration in terms of Heidegger's notion of the everyday, Al/staglichkeit. 'In the everyday we have no name, little personal reality, scarcely a figure, just as we have no social determination to sustain or enclose us. ${ }^{14}$ Language is without moorings since words are bound through obscurity to the signifieds, and thus work inoperatively: shades of forgetting, to the point of a silence 'that has already dissipated as soon as we keep still in order to hear it . . . in the unspeaking speech that is the soft human murmuring in us and around us. ${ }^{15}$ Anonymous, subjectless, indeterminate, ineffectual: the everyday is the diffuse focal point of forgetting. 'Radical nihilism' is what Blanchot calls it; its impotency has the effect of denying the possibility of a beginning. In its strangeness, forbidding the idea of creation, everydayness is the uncreated. [Hence, '[e]veryday man is the most atheist of men. ${ }^{16}$

Forgetting is also secret. As the protagonist of Awaiting Oblivion says, 'to welcome forgetting as the accord with that which is hidden, the latent gift.' ${ }^{17}$ Concealment [Verborgenheit], hidden, secret, sacred. It is this chain that Blanchot thinks through in his investigation of absolute forgetting [Vergessenheit]. By homonymy in the French (le don latent and le don l'attend), there is a further link with waiting. In waiting, one takes an attitude that corresponds to forgetting. Such waiting would have to be intransitive, neither for this or that or the other thing. Figuratively, it is embodied in the figure of Odysseus tied to the mast as the ship approaches the sirens' lair. In him are

\footnotetext{
${ }^{14}$ The Infinite Conversation, p. 242.

15 idem

16 lbid., p. 245.

17 Op. cit., p. 45.
} 
glimpsed the aspects of a welcome that yields no access because the outside is not enclosed by any interior. They are 'silence, discretion, forgetfulness.'18 The movement of a passive disengagement, surprising and refreshing, becomes apparent. Acceptance of the gift latent with forgetting makes 'a game of human time and out of that game to create a free occupation, one stripped of a immediate interest and usefulness, essentially superficial and yet in its surface movement capable of absorbing all being. ${ }^{19}$

Game time is not human time. Time that contains the possibility of presence-everyday time-is not the time of waiting-forgetting. As Blanchot writes, 'Waiting that takes place in time opens time to the absence of time, where there is no reason to wait.' ${ }^{20}$ Game time is thus the other time or otherwise than time. For one thing, it lacks the repeated endeavor of the project [Entwurf], of being ahead of oneself in order to catch up with oneself in the present. This absence is what allows Blanchot to describe Orpheus's failing as one of waiting, with patience; 'patience is the ruse which seeks to master this absence by making of it another time, measured otherwise. ${ }^{21}$ In his quest to return Eurydice to earth, he ceases to be disinterested, diverted by the scenery, disengaged, light-hearted. He ceases to think a thought of waiting, 'thought that is the waiting for that which does not let itself be thought, thought borne by waiting that is adjourned in this waiting. ${ }^{22} \mathrm{He}$ ceases to move in game time, its suspension of gravity, its innocence and lack of concern, and its easy concentration on the flight of images and simulacra.

Is it possible to understand more fully the reverse movement-into the otherwise than time, game time? The lack of concern goes by the name of insouciance, a kind of concentrated heedlessness, nonattachment, or, in phenomenological terms, reduction. One steps back from being-in-the-world, engaging not the ontological difference and call of conscience, but rather what Blanchot labels a 'movement of sacrifice.' ${ }^{23}$ The easy equation of the reduction with sacrifice provides the cornerstone for the human encounter with the sacred. Here, the hidden is allowed to be hidden, the forgetting forgotten, the secret preserved. Such allowance, which perhaps is Gelassenheit itself, is inadvertent. It cannot be deliberate, purposeful, or goaloriented activity. In 'a sacrifice without ceremony, where the sacred itself, night in its unapproachable profundity,

\footnotetext{
18 'The Song of the Sirens,' in The Station Hill Blanchot Reader, tr. Lydia Davis, Paul Auster, and Robert Lamberton. Barrytown: Station Hill, 1999, p. 446.

${ }^{19}$ idem

${ }^{20}$ Awaiting Oblivion, p. 51.

${ }^{21}$ Maurice Blanchot, 'Orpheus' Gaze,' in The Space of Literature, tr. Ann Smock. Lincoln: University of Nebraska Press, 1982, p. 173. SL

${ }^{22}$ Awaiting Oblivion, p. 53.

${ }^{23}$ The Space of Literature, p. 175.
}

is given back ... to the inessential, which is not the profane but less than any such category,' there is no one who officiates. ${ }^{24}$ If a reduction without intentionality can be accomplished at all, only a subjectivity without a subject is capable of it. But perhaps that is what intransitive forgetting is about: enucleation of a subjectplace such that what happens happens by virtue of no one at all. At that point, subjectivity is not different from objectivity; the lines of distinction have become deformed.

The strange movement of a reduction that is otherwise than a reduction. In phenomenology, suspension of the 'natural attitude' that posits existence to the objects of consciousness yields a field in which vectors of intentionality delineate that at which awareness points. By assignation of meanings to the vectors, phenomenology is able to move from ontology to semiology. Signification takes precedence over being. Transformed under Blanchot's gaze, the reduction, a 'movement of sacrifice', now suspends not only existence but also meaning. Holding the meaning in abeyance, withdrawing consciousness from the semantic field, leaves the transcendental ego without orientation, adrift, lost in a domain where linguistical fragments stream in excess but where, lacking a point of stability, (non-) experience is a senseless flux. ${ }^{25}$ A consciousness belonging to no one that, having no object, is powerless to disengage, because it has always already annulled its engagement. A consciousness that sees without the protection of the object and hence, is totally exposed to forces that menace its integrity at every step. A consciousness so dilated that it cannot but be susceptible to the onslaught of the outside and the pandemonium it invites.

The cost of sacrifice, accomplished through negligence, is nothing other than the suffering one's own nothingness. Bereft of the law of identity, one is cast beyond the pale, into the desert of thought. For Orpheus (who is divine), this is 'the moment when he frees himself from himself.' Experienced humanly, as Lawlor observes: 'one must feel naked and defenseless so that one undergoes the presence of the outside, that is, one must be in the void, naked and defenseless, and yet undergo the feeling that one is still not inside the outside.'26 The 'extreme moment of liberty' is the extreme torsion of spirit. Liberation amounts to forgetting being-in-the-world (authentically, inauthentically), surrendering the place of belonging to the weak force that undoes all appropriative forms, including designatory ones. In the teeth of terror (the underworld, the sirens), brought forth by distraction and

\footnotetext{
24 idem

${ }^{25}$ Lawlor will call this 'multiplicity'; Foucault speaks of 'language in its raw being.' Leonard Lawlor, Early Twentieth-Century Continental Philosophy, Bloomington: Indiana University Press, 2012, p. 197.

${ }^{26}$ Ibid., p. 185.
} 
diversion, one has cleared the scene for work of the sacred. Anarchical, transgressive, forceful, subtle: the work as emissary of the sacred exposes the least human part of one's humanity - the part least capable of claiming it for one's own. 'Not my will, but Thine.'

It might appear that a passive attention, one possessed by fascination and rendered oblivious to the world, would be dissipated and flaccid. This is not the case. Foucault observes that a reduction via negligence is, to use a religious term, a kind of zeal —not unlike a passion for learned ignorance. Zeal and negligence are 'two indefinitely reversal figures.' ${ }^{27}$ An impassive passion of 'letting oneself be attracted by attraction . . . to being the aimless movement without a moving body of attraction itself in the void,' zeal is the remainder after one has reduced all other expressions of affectivity. ${ }^{28}$ Zeal is able to make a stand in the face of terror since it itself is 'a courageously negligent solicitude, in going toward the light in negligence of shadow, until it is discovered that the light itself is only negligence, a pure outside equivalent to a darkness that disperses, like a blown-out candle, the negligent zeal it had attracted. ${ }^{29}$ Zeal: what endures the negligent play of light and darkness in the absolute dissolution of the world.

Of course it is the writer who displays this sort of courage on the ramparts that overlook the outside. The writer, the heir to the witness of Odysseus, of Orpheus. He or she makes 'a game of human time and out of that game to create a free occupation, one stripped of all immediate interest and usefulness, essentially superficial and yet in its surface movement capable of absorbing all being. ${ }^{30}$ Just as zeal animates a confrontation with one's nothingness, so too the writerly impulse is the opposite of slackness and nonchalance. The high tonality that springs from a profound and waiting silence, Blanchot writes, produces the spark which extreme tension ignites as the brilliant point which has escaped this mindful wait-the glad accident, insouciance. ${ }^{31}$

The legacy of such art (its carelessness and lack of concern) belongs to the reader. While avoiding the threat of the essential solitude of the writer, one joins the gamesmanship found in writing. Of reading, Blanchot says: 'It shares . . . the lightness, the irresponsibility, the innocence of the decision' to write. ${ }^{32}$ The reader thus makes herself available to the unworking force that literature shrouds. In the gesture lies the tacit affirmation of reading, whose essence is

\footnotetext{
${ }^{27}$ Michel Foucault, 'Maurice Blanchot: The Thought from Outside,' in Foucault/Blanchot, tr Jeffrey Mehlman and Brian Massumi. New York: Zone Books, 1990, p. 30.

28 Ibid., p. 31

${ }^{29} \mathrm{lbid}$., pp. 30-31.

30 'The Song of the Sirens,' p. 446.

31 'Orpheus' Gaze,' o, 176.

32 'Reading,' in The Station Hill Blanchot Reader, p. 435.
}

'the freedom of this Yes.' ${ }^{33}$ The affirmation is special. Indicative of a lightness that prefigures a disappearance, we should not take the reader's lightness lightly. It is a consent without self-reflection, directed only to the linguistic game-that which abjures human time. There, the referents blur unblended in the deconstructive force of the murmuring sirens song, and form, specificity, and difference lose their footing. What is there is less there, to the vanishing point, i.e., nondifferentiation. Things themselves have surrendered their specific limits so that the reader says 'yes' only to their being at hand [Vorhandensein]. The two sides of lightness open to an insobriety that harbors no regrets for the absent identities. Drawing on Nietzsche's Zarathustra, Blanchot describes the last man-at the limits of his humanity - in the image of the reader. Both need to dismantle a determinate world in order to approach the beginning, that is, the neutral presence of being out of which the literary work emerges. Both respectfully succumb to the inhuman song, sung humanly by the sirens, and come close to the point of all initiation. Both surrender the means of production of signification-analysis, critique, interpretation-in order to allow a reading that does not sound in opposition to the text. Such a reading (could we say a close reading?) then echoes the counsel of the last man:

First to forget. To remember only there where one remembers nothing. To forget to remember everything as though by way of forgetting. There is a profoundly forgotten point from which every memory radiates. Everything is exalted in memory starting from something forgotten, an infinitesimal detail, a miniscule fissure into which it passes in its entirety. ${ }^{34}$

'To remember forgetfully: again, the outside.' ${ }^{35}$ In the wedge that the disaster drives between language and the power of the real, the impotency of amnesia acquires a subtle force. To abandon the 'ends of man', the arche, beginning or principle, can permit thought to wait, and in waiting, 'to await the future,' as Lawlor says. ${ }^{36}$ This suggests that, for Blanchot, forgetting is essentially bound up with eschatology and messianism. Contact with the outside provides purification, dislodging memory-traces that impede receptivity to what is to come. It is the dark gaze that Kevin Hart apotheosizes, at the center of Blanchot's 'counterspirituality. ${ }^{37}$ Stripping one of the source of pretension and hubris, it absolves also of the misshapen form of humanity associated with being-in-the-world. This

\footnotetext{
33 idem

${ }^{34}$ Maurice Blanchot, The Last Man, tr. Lydia Davis. New York: Columbia University Press, 1987, p.

${ }^{35}$ The Writing of the Disaster, p. 3.

${ }^{36}$ Op. cit., p. 145

${ }^{37} \mathrm{Cf}$. 'mystery abides in how one sees, not in a transcendent being, in the dark gaze rather than in the lumen fidei.' Kevin Hart, The Dark Gaze: Maurice Blanchot and the Sacred, Chicago: University of Chicago Press, 2004, p. 160.
} 
distortion has much to do with the wall, line, barrier, or barricade erected that seals off an inside in opposition to an outside. To encounter the outside (experience of non-experience) is to meet with that which cannot be enclosed since it lacks any interior. One simply awaits a future whose imminence deepens the patience to endure.

There is another measure of messianism in Blanchot's thought. It corresponds to the lore that locates the messiah-to-come among the lepers below the city's ramparts. That is, forgetting is constituted in the form of Nietzsche's 'active oblivion,' an agency meant to clear the mind of memory-traces so that it might be acutely aware of the formless (un)working of creative energies. The repeated wiping the slate clean shares common ground with Bergson's (and Deleuze's) 'memory of the present,' that, like an after-image, appears in its disappearance and like a pure aperture, gives itself wholly over to what is currently there. Both thoughts recompose the present in terms of a virtuality in which presence vanishes into a becoming-actual or a being-creative. Oriented by the twin poles of no longer and not yet, memory of the present has always already emerged from an encounter with nothingness, and has reckoned the wages of living on, in contrast to those of death and dying. It is not shackled by appropriative impulses that would 'territorialize' virtuality and repeatedly actualize the same as the last time. It has ante-ed the price of freedom-submission to anonymity and anarchy - and waits in an endlessness that is totally aligned with patience. It is not Hamlet's 'readiness is all' but a way of aimless improvisation, an awareness of an impersonal cosmic drama in which game is to play a part, no matter which.

Waiting, one forgets. One forgets the messiah, the coming messiah, the coming of the messiah. Viens is the operative thought, as Derrida says. Come nearer, even though de-distancing [Entfernung] has been annulled. To be bathed by the energies of the void is a kind of baptism, the second baptism, to be exact. The trial by fire ('singe-less flames') opens thought to the 'latent gift,' a radical reorientation of thought's province. 'To think,' Blanchot tells us near the end of The Writing of the Disaster, 'is to approach the thought of the One which strictly escapes thought, even though thought is turned toward the One as the needle of the compass toward the pole which it does not indicate-turned?'38 Such a One differs from a medieval transcendental as much as from 'God.' Turning from all names, one worships the absolute escape, deferring the end of turning as long as the freshness and vitality of forgetting animate the process.

\footnotetext{
${ }^{38}$ The Writing of the Disaster, p. 140.
} 